\title{
Nutrient Management in Fragrant Rice: A Review
}

\author{
Newton Chandra Paul1 (ㄷ, Mst. Tamanna Tasmim², Shahin Imran1, Md. Asif Mahamud³, \\ Jotirmoy Chakrobortty4, Rakibul Hasan Md. Rabbi ${ }^{3}$, Shubroto Kumar Sarkar ${ }^{5}$ (D), \\ Swapan Kumar Paul ${ }^{*}$
}

\author{
${ }^{1}$ Department of Agronomy, Khulna Agricultural University, Khulna, Bangladesh \\ ${ }^{2}$ Department of Horticulture, Bangladesh Agricultural University, Mymensingh, Bangladesh \\ ${ }^{3}$ Department of Agricultural Chemistry, Khulna Agricultural University, Khulna, Bangladesh \\ ${ }^{4}$ Department of Soil Science, Khulna Agricultural University, Khulna, Bangladesh \\ ${ }^{5}$ Department of Agronomy, Bangladesh Agricultural University, Mymensingh, Bangladesh \\ Email: *skpaul@bau.edu.bd
}

How to cite this paper: Paul, N.C., Tasmim, M.T., Imran, S., Mahamud, M.A., Chakrobortty, J., Rabbi, R.H.M., Sarkar, S.K. and Paul, S.K. (2021) Nutrient Management in Fragrant Rice: A Review. Agricultural Sciences, 12, 1538-1554. https://doi.org/10.4236/as.2021.1212098

Received: November 21, 2021

Accepted: December 26, 2021

Published: December 29, 2021

Copyright (c) 2021 by author(s) and Scientific Research Publishing Inc. This work is licensed under the Creative Commons Attribution-NonCommercial International License (CC BY-NC 4.0). http://creativecommons.org/licenses/by-nc/4.0/

\begin{abstract}
Rice (Oryza sativa L.) is the most important cereal food grain crop and is consumed by the majority of the world's human population. Among all cultivars, fragrant/aromatic rice is preferred by the better part of the human population because of its aroma, taste and cooking quality. But most of the fragrant rice varieties are low yielding and easily sensitive to the surrounding environmental condition. Among different agronomic performances, proper nutrient management can improve the yield of fragrant rice not only by giving the required amount of nutrients but also by maintaining the health of the soil and the quality of the produce. In most cases, traditional agricultural practices degraded soil health and increased environmental pollution which leads to inferior grain quality. On the other hand, excessive application of chemical fertilizers reduced the nutrient status of the soil and badly affected the soil productivity and environmental stability. Therefore, a suitable approach of nutrient management is required to keep the production of fragrant rice to a notable amount and increase the nutrient use efficiency of soil. Application of manures and fertilizers in an appropriate dose which is the main object of nutrient management is required for its utmost importance in the growth and development of the crop that finally results in better yield and grain quality. Therefore, nutrient management is an important aspect in aromatic rice production to attain sustainable grain yield and high economic return with better quality of produce.
\end{abstract}

\section{Keywords}

Nutrient Management, Fragrant Rice, Growth, Yield, Grain Quality 


\section{Introduction}

Rice (Oryza sativa L.) is the second most important field crop after wheat consumed as a staple food and an indispensable source of calories for almost half of the population due to its everyday consumption in Asia [1]. Depending on the presence of aroma on the grain, rice is classified into aromatic and non-aromatic rice worldwide. In recent years, fragrant/aromatic rice varieties have occupied a prime position in national and international markets because of their excellent taste, deliciousness, milling and eating quality to attract rice consumers and the high price which boosts the economic condition of the rice growers [2]. Due to the change of the consumer's preference for better quality rice, the demand for aromatic rice varieties has increased globally to a great extent over the past few years [3]. But the productivity of the scented rice cultivars is rather low compared to coarse and medium rice varieties [4]. In the modern era, the high yielding potential and quality advantage of the scented rice varieties over conventional rice varieties may open a new chapter for the export of high-quality scented rice [5]. So, it is important to obtain a higher yield with maintaining its quality too from scented rice varieties [3]. Therefore, there is a need to adopt modern farming practices and cultivate scented rice varieties with intensive nutrient management to increase the growth and produce crops in line with the observed global standards of quantity and quality. In modern farming, use of chemical fertilizer is an essential component of rice production [6] but extensive and improper use of chemical fertilizers in the soil was found to increase yield only for a few years but the long-term causes soil degradation at an alarming level [7]. Organic manures enhanced rice production by accelerating plant growth, increasing yield and quality of agricultural produce and at the same time by maintaining soil health that keeps the field more fertile [8]. On the other hand, low $\mathrm{N}$ and $\mathrm{K}$ content was observed at the mid-tillering stage of rice plants due to continuous application of injudicious organic fertilizer alone on rice fields resulting in lower yield [9]. In addition, the combined application of organic manures and inorganic fertilizers in rice field provides favorable soil physical conditions and increases the efficiency of applied nutrients that helps to maintain yield stability through correction of marginal deficiencies of secondary and micronutrients [10]. Therefore, the objective of this paper is to ample review the literature and find out the best dose of fertilizers and manures for sustainable fragrant rice production and soil properties enhancement.

\section{Influence of Nutrient Management in Fragrant/Aromatic Rice Production}

\subsection{Role on Growth Traits}

Vegetative growth is a vital factor that determines the productivity of rice. $\mathrm{Ni}$ trogen $(\mathrm{N})$, phosphorus $(\mathrm{P})$, and potassium $(\mathrm{K})$ are considered as primary nutrients and are very important for the growth and development of rice [11]. Ni- 
trogen is responsible for vegetative growth, improving the leaf area index, chlorophyll synthesis, increasing photosynthesis and assimilating production in plants [12]. Phosphorus is known for its role in root growth, root development, and reproduction [13]. $\mathrm{P}$ is also known to improve tillering and promote early flowering. Potassium, though not a constituent of organic structures of plants, is very important for plant strength, resistance to biotic and abiotic stresses, and stomatal activity [14]. According to Kundu et al. [15] 50\% N through urea (N @ $\left.40 \mathrm{~kg} \mathrm{ha}^{-1}\right)+50 \% \mathrm{~N}$ through vermicompost $\left(\mathrm{N} @ 40 \mathrm{~kg} \mathrm{ha}^{-1}\right)+\mathrm{P} @ 20 \mathrm{~kg} \mathrm{ha}^{-1}+$ $\mathrm{K} @ 20 \mathrm{~kg} \mathrm{ha}^{-1}$ recorded the tallest plant (Figure 1), the highest values of total dry matter (TDM) and leaf area index (LAI) at all crop growth stages. In a study, Nila et al. [16] reported that incorporation of poultry manure (PM) @ $2.5 \mathrm{t} \mathrm{ha}^{-1}$ with curtailed 25\% from recommended dose of inorganic fertilizers (RDF) of N-P-K-S-Zn @ 115-25-60-18-3.5 kg ha ${ }^{-1}$ produced the tallest plant, the highest number of tillers hill ${ }^{-1}$ (Figure 2), LAI and TDM of aromatic Boro rice BRRI dhan50. Whereas application of $75 \%$ of RDF of urea-TSP-MoP-gypsumzinc-sulphate @ 150-97-70-60-12 $\mathrm{kg} \mathrm{ha}^{-1}$, respectively + 50\% cowdung @ $5 \mathrm{t} \mathrm{ha}^{-1}$ produced the tallest plant, the highest number of tillers hill ${ }^{-1}$, LAI (Figure 3), TDM and crop growth rate (CGR) [17]. On the other hand, Roy et al. [18] opined that application of manure with inorganic fertilizers which regulated the exuberant vegetative growth produced the tallest plant, the highest number of tillers hill ${ }^{-1}$ and LAI of BRRI dhan38 when fertilized with $75 \%$ of RDF of urea-TSP-MoP-gypsum-ZnSO ${ }_{4} @$ 150-97-70-60-12 kg ha ${ }^{-1}$, respectively + PM @ $2.5 \mathrm{t} \mathrm{ha}^{-1}$. While, the treatment $75 \%$ of $\mathrm{RDF}$ of urea-TSP-MoP-gypsum- $\mathrm{ZnSO}_{4}$

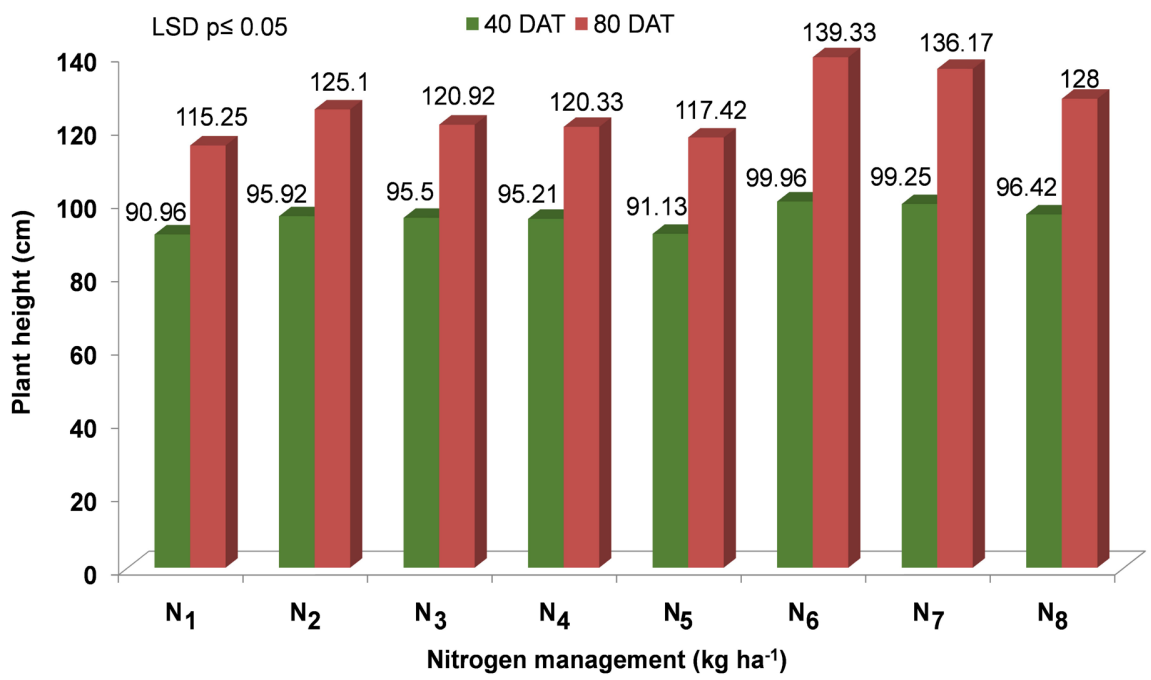

Figure 1. Effect of integrated nitrogen management on plant height $(\mathrm{cm})$ aromatic Boro rice (cv. BRRI dhan50) at different days after transplanting. $\mathrm{N}_{1}=$ Control, $\mathrm{N}_{2}=\mathrm{RDF}$ $\left(40: 20: 20 \mathrm{NPK} \mathrm{kg} \mathrm{ha}^{-1}\right), \mathrm{N}_{3}=100 \% \mathrm{~N}$ through vermicompost $+\mathrm{P}+\mathrm{K}, \mathrm{N}_{4}=50 \% \mathrm{~N}$ through vermicompost $+50 \% \mathrm{~N}$ through $\mathrm{FYM}+\mathrm{P}+\mathrm{K}, \mathrm{N}_{5}=100 \% \mathrm{~N}$ through $\mathrm{FYM}+\mathrm{P}+\mathrm{K}, \mathrm{N}_{6}=$ $50 \% \mathrm{~N}$ through urea $+50 \% \mathrm{~N}$ through vermicompost $+\mathrm{P}+\mathrm{K}, \mathrm{N}_{7}=50 \% \mathrm{~N}$ through urea + $25 \% \mathrm{~N}$ through vermicompost $+25 \% \mathrm{~N}$ through $\mathrm{FYM}+\mathrm{P}+\mathrm{K}$ and $\mathrm{N}_{8}=50 \% \mathrm{~N}$ through urea $+50 \% \mathrm{~N}$ through FYM $+\mathrm{P}+\mathrm{K}$ in subplots. Source: Kundu et al. [15]. 


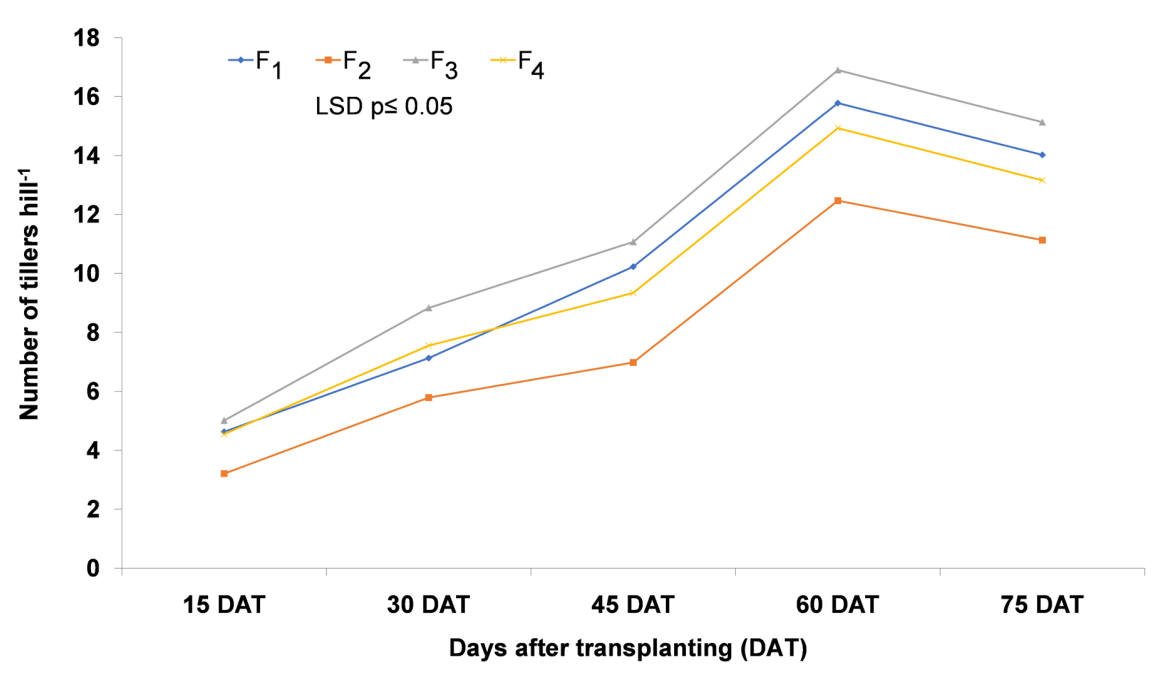

Figure 2. Effect of nutrient management on number of tillers hill ${ }^{-1}$ of aromatic Boro rice (cv. BRRI dhan50) at different days after transplanting. $\mathrm{F}_{1}=\mathrm{RDF}(\mathrm{N}, \mathrm{P}, \mathrm{K}, \mathrm{S}$ and $\mathrm{Zn}$ at the rate of $115,25,60,18,3.5 \mathrm{~kg} \mathrm{ha}^{-1}$ respectively), $\mathrm{F}_{2}=\mathrm{PM} 5 \mathrm{t} \mathrm{ha}^{-1}, \mathrm{~F}_{3}=25 \%$ less than $\mathrm{RDF}+2.5 \mathrm{t} \mathrm{ha}^{-1} \mathrm{PM}, \mathrm{F}_{4}=50 \%$ less than RDF $+2.5 \mathrm{tha}^{-1} \mathrm{PM}$. Source: Nila et al. [16].

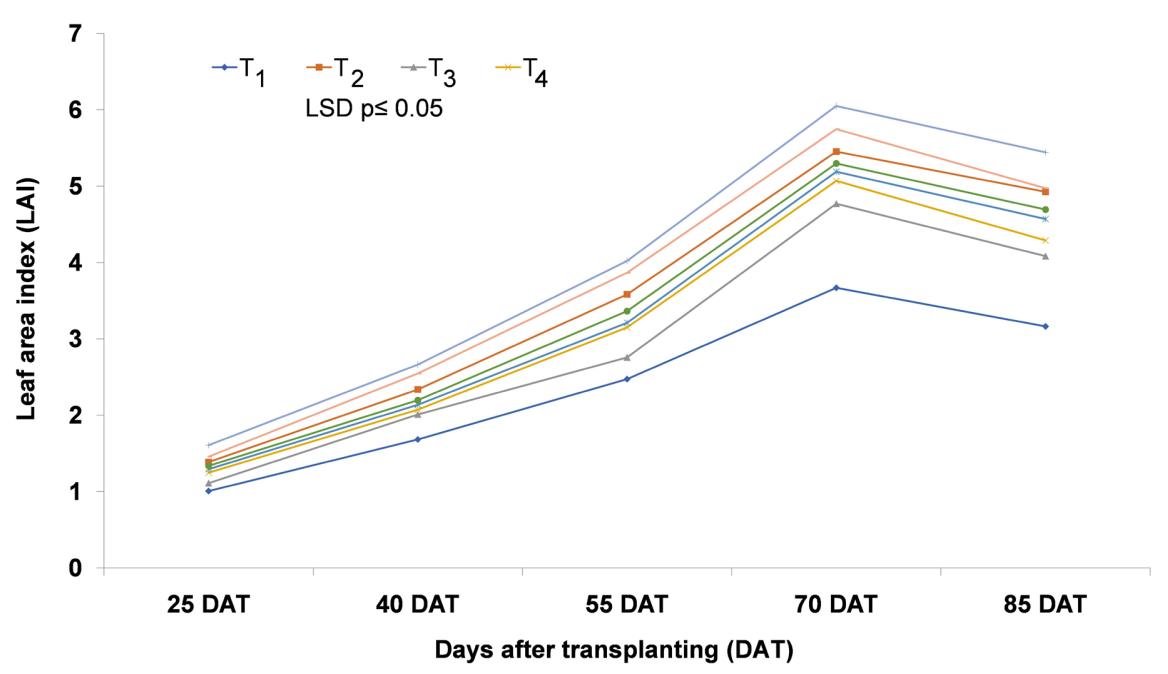

Figure 3. Effect of nutrient management on leaf area index (LAI) of aromatic fine rice at different days after transplanting. $\mathrm{T}_{1}=$ control (no manures and fertilizers), $\mathrm{T}_{2}=\mathrm{RDF}$ (i.e. $150,97,70,60$ and $12 \mathrm{~kg}$ urea, TSP, MoP, gypsum and $\mathrm{Zn}$ respectively ha ${ }^{-1}, \mathrm{~T}_{3}=$ cowdung @ $10 \mathrm{t} \mathrm{ha}^{-1}, \mathrm{~T}_{4}=\mathrm{PM} @ 5 \mathrm{t} \mathrm{ha}^{-1}, \mathrm{~T}_{5}=50 \%$ of RDF $+50 \%$ cowdung, $\mathrm{T}_{6}=50 \%$ of RDF + $50 \% \mathrm{PM}, \mathrm{T}_{7}=75 \%$ of RDF $+50 \%$ cowdung, $\mathrm{T}_{8}=75 \%$ of RDF $+50 \%$ PM. Source: Sarkar et al. [17].

@ 150-97-70-60-12 kg ha ${ }^{-1}$, respectively + PM @ $2.5 \mathrm{t} \mathrm{ha}^{-1}$ increased the nutrient availability in the soil and their uptake by plants recorded the tallest plant, the highest number of tillers hill ${ }^{-1}$, TDM (Figure 4) and CGR of BRRI dhan38 [19]. Similar results were found by Roy et al. [20] who revealed that $75 \%$ of RDF of urea-TSP-MoP-gypsum-ZnSO ${ }_{4} @$ 250-120-120-100-10 kg ha ${ }^{-1}$, respectively + PM@ $2.5 \mathrm{t} \mathrm{ha}^{-1}$ influenced plant growth resulted the tallest plant, the highest number of tillers hill ${ }^{-1}$, LAI, TDM and CGR (Figure 5) of BRRI dhan50. In 


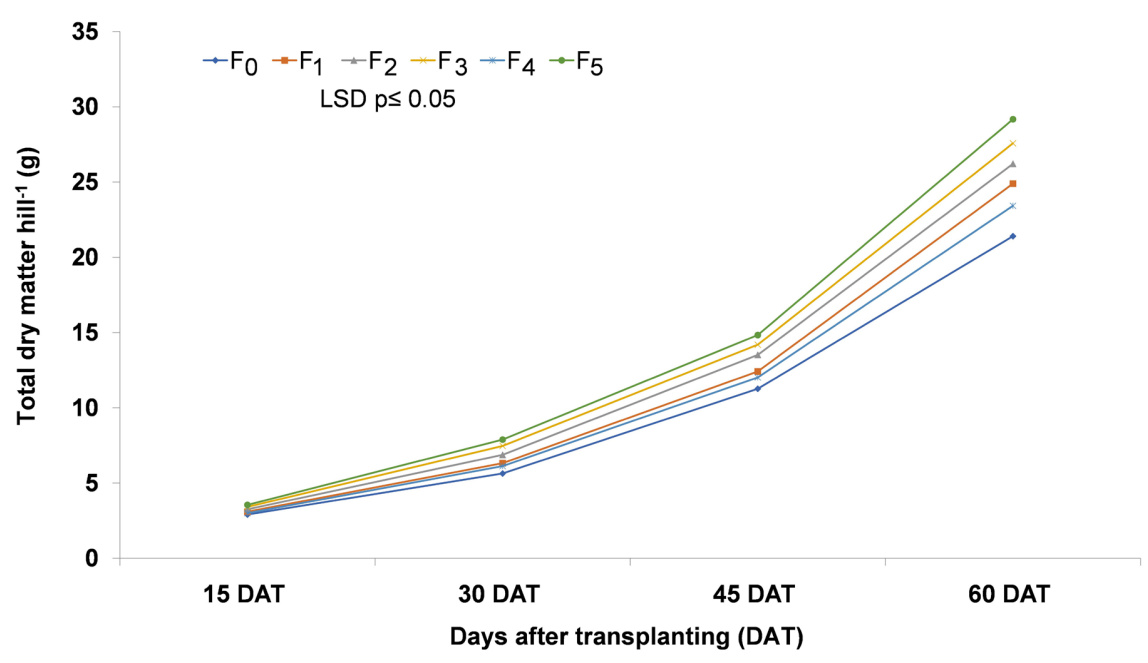

Figure 4. Effect of nutrient management on total dry matter hill ${ }^{-1}$ of aromatic rice (cv. BRRI dhan38) at different days after transplanting. $\mathrm{F}_{0}=$ Control (no manures and fertilizers), $\mathrm{F}_{1}=\mathrm{RDF}, \mathrm{F}_{2}=50 \%$ of RDF + cowdung @ $5 \mathrm{t} \mathrm{ha}^{-1}, \mathrm{~F}_{3}=75 \%$ of RDF + cowdung @ $5 \mathrm{t} \mathrm{ha}^{-1}, \mathrm{~F}_{4}=50 \%$ of RDF + PM @ $2.5 \mathrm{tha}^{-1}, \mathrm{~F}_{5}=75 \%$ of RDF + PM @ $2.5 \mathrm{t} \mathrm{ha}^{-1}$. Source: Roy et al. [19].

another study, Paul et al. [21] revealed that application of $150 \mathrm{~kg} \mathrm{~N} \mathrm{ha}^{-1}$ along with $90 \mathrm{~kg} \mathrm{~K} \mathrm{ha}^{-1}$ performed best in terms of leaf dry matter, culm dry matter, panicle dry matter and TDM production hill ${ }^{-1}$ of BRRI dhan50 at all the growth stages. Sharma et al. [22] stated that higher levels of nitrogen availability improved growth components viz. the tallest plant, the highest number of tillers and TDM of basmati rice when fertilized with $160 \mathrm{~kg} \mathrm{~N} \mathrm{ha}^{-1}$ over other doses of $\mathrm{N}$. The favorable synthesis of growth promoting constituents in plant system owing to better supply of nutrients resulted in the tallest plant, the highest number of tillers, LAI and TDM at all the stages from the treatment received 50\% recommended N-P-K @120-60-60 kg ha ${ }^{-1}+50 \%$ recommended N through farmyard manure (FYM) $+5 \mathrm{~kg} \mathrm{zinc} \mathrm{ha}^{-1}[23]$.

\subsection{Role on Yield Components}

The yield components of rice are the number of panicles per unit area, number of spikelet per panicle, weight of spikelet and spikelet sterility or filled spikelet. In addition, shoot dry weight, grain harvest index, and nitrogen $(\mathrm{N})$ harvest index are also positively associated with grain yield [24]. In a study, Hossain et al. [25] conducted an experiment to optimize the nitrogen rate for aromatic rice, where the maximum number of effective tillers hill ${ }^{-1}$, the longest panicle (Figure 6 ), the highest number of grains panicle ${ }^{-1}$ and 1000-grain weight were found when fertilized with $45 \mathrm{~kg} \mathrm{~N} \mathrm{ha}^{-1}$. While Jahan et al. [26] reported that the maximum number of effective tillers hill ${ }^{-1}$, panicle length and 1000-grain weight were observed from $60 \mathrm{~kg} \mathrm{~N} \mathrm{ha}^{-1}$ which increases the nitrogen availability in soil. The highest number of effective tillers hill ${ }^{-1}$, panicle length and number of grains panicle $^{-1}$ (Figure 7) were found from $50 \%$ less than RDF of urea-TSP-MoP- 


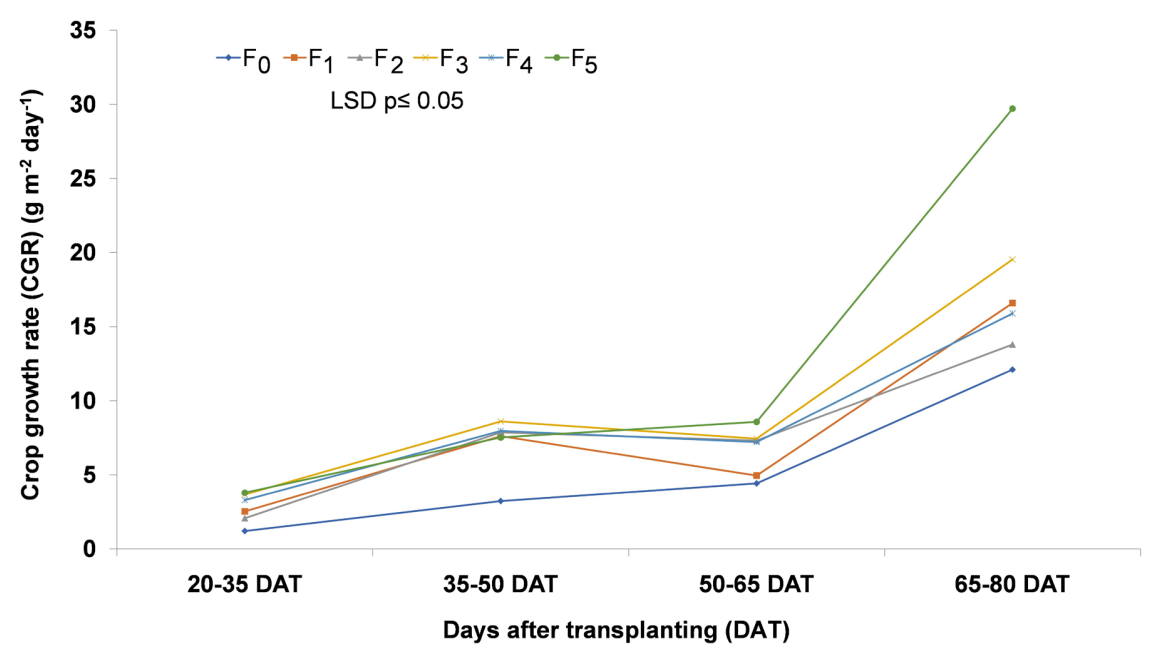

Figure 5. Effect of integrated fertilizer management on crop growth rate $\left(\mathrm{g} \cdot \mathrm{m}^{-2} \cdot \mathrm{day}^{-1}\right)$ at different days after transplanting of aromatic Boro rice (cv. BRRI dhan50). $\mathrm{F}_{0}=$ Control (no fertilizer and no manure), $\mathrm{F}_{1}=\mathrm{RDF}$ (urea, TSP, MoP, gypsum, $\mathrm{ZnSO}_{4} @ 250,120$, $120,100,10 \mathrm{~kg} \mathrm{ha}^{-1}$, respectively), $\mathrm{F}_{2}=50 \%$ of $\mathrm{RDF}+$ cowdung @ $5 \mathrm{t} \mathrm{ha}^{-1}, \mathrm{~F}_{3}=75 \%$ of $\mathrm{RDF}+$ cowdung @ $5 \mathrm{t} \mathrm{ha}^{-1}, \mathrm{~F}_{4}=50 \%$ of RDF + PM@ $2.5 \mathrm{t} \mathrm{ha}^{-1}, \mathrm{~F}_{5}=75 \%$ of RDF + PM @ $2.5 \mathrm{t} \mathrm{ha}^{-1}$. Source: Roy et al. [20].

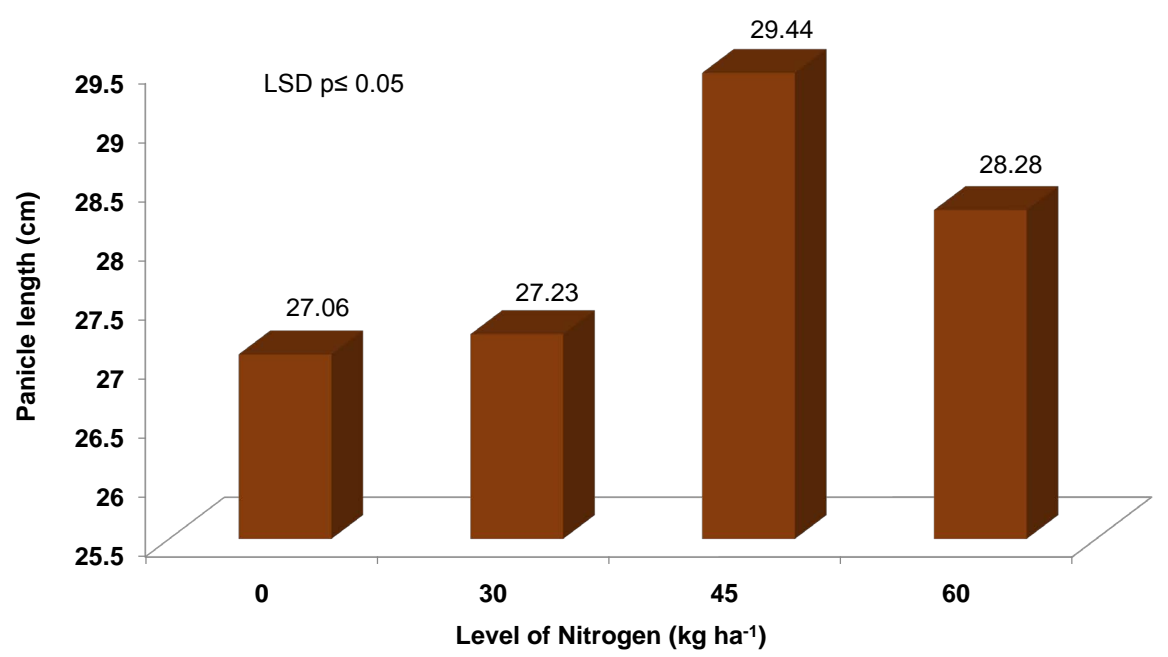

Figure 6. Effect of nitrogen levels on panicle length $(\mathrm{cm})$ of aromatic rice. Source: Hossain et al. [25].

gypsum-zinc sulphate @ 150-95-70-60-12 kg ha ${ }^{-1}$, respectively + vermicompost @ $3 \mathrm{t} \mathrm{ha}^{-1}$ due to the enhanced and continuous supply of nutrients by the combination of vermicompost and inorganic fertilizer [27]. In addition, application of USG (urea super granule) @ $1.8 \mathrm{~g} 4$ hills $^{-1}$ produced the highest number of effective tillers hill ${ }^{-1}$, panicle length, number of grains panicle ${ }^{-1}$ and 1000-grain weight compared to other doses [28]. Again, the highest number of effective tillers hill ${ }^{-1}$, panicle length, number of grains panicle ${ }^{-1}$ and 1000-grain weight (Figure 8) of BRRI dhan 50 were recorded when the crop was fertilized with $25 \%$ less than RDF of N-P-K-S-Zn@ 115-25-60-18-3.5 kg ha ${ }^{-1}$, respectively + PM @ 2.5 t 


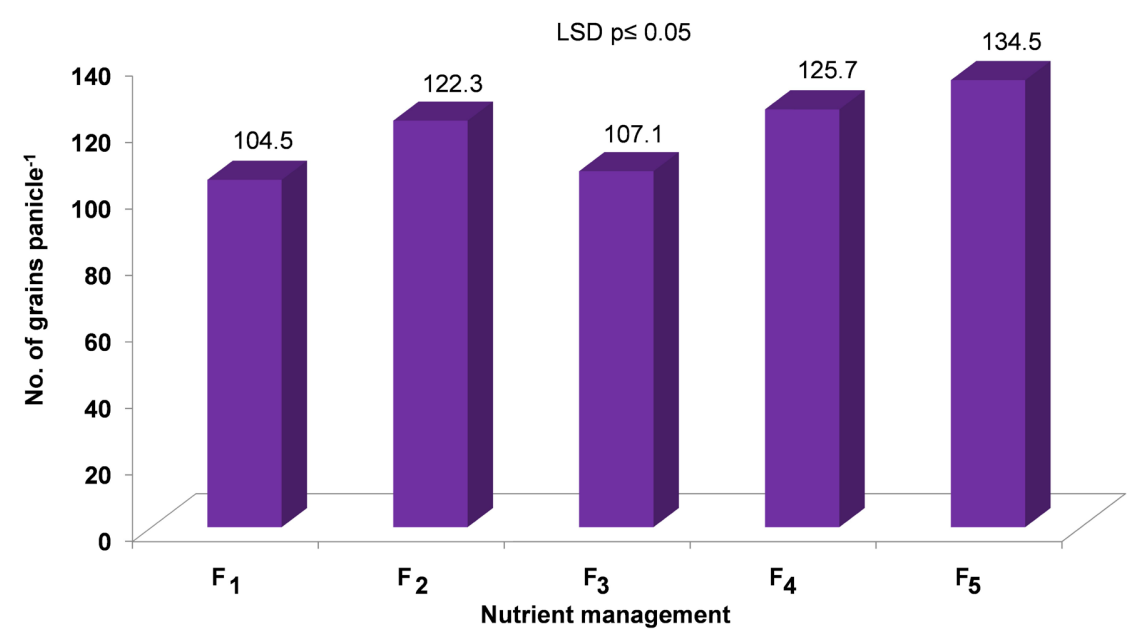

Figure 7. Effect of nutrient management on number of grains panicle ${ }^{-1}$ of aromatic fine rice. $F_{1}=$ Control (no manures and fertilizers), $F_{2}=\mathrm{RDF}$ (i.e. 150, 95, 70, 60 and $12 \mathrm{~kg}$ $\mathrm{ha}^{-1}$ of urea, TSP, MoP, gypsum and zinc sulphate, respectively), $\mathrm{F}_{3}=$ vermicompost @ $3 \mathrm{t}$ $\mathrm{ha}^{-1}, \mathrm{~F}_{4}=25 \%$ less than RDF + vermicompost @ $1.5 \mathrm{t} \mathrm{ha}^{-1}, \mathrm{~F}_{5}=50 \%$ less than RDF + vermicompost@ $3 \mathrm{tha}^{-1}$. Source: Laila et al. [27].

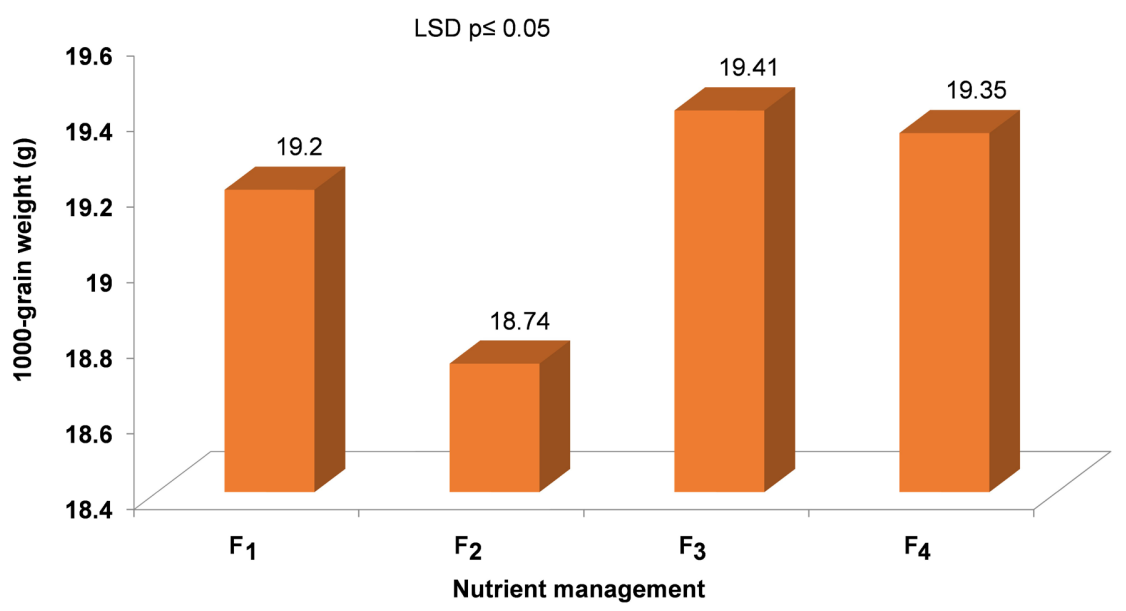

Figure 8. Effect of nutrient management on 1000-grain weight of aromatic Boro rice (cv. BRRI dhan50). $\mathrm{F}_{1}=\mathrm{RDF}\left(\mathrm{N}, \mathrm{P}, \mathrm{K}, \mathrm{S}\right.$ and $\mathrm{Zn}$ at the rate of $115,25,60,18,3.5 \mathrm{~kg} \mathrm{ha}^{-1}$, respectively), $\mathrm{F}_{2}=\mathrm{PM} @ 5 \mathrm{t} \mathrm{ha}^{-1}, \mathrm{~F}_{3}=25 \%$ less than $\mathrm{RDF}+2.5 \mathrm{tha}^{-1} \mathrm{PM}, \mathrm{F}_{4}=50 \%$ less than RDF + $2.5 \mathrm{t} \mathrm{ha}^{-1}$ PM. Source: Paul et al. [29].

$\mathrm{ha}^{-1}$ by improving soil aeration, water holding capacity and microbial activity [29]. Application of 150\% N (i.e. N@60 kg ha ${ }^{-1}$ ) + FYM @ $10 \mathrm{t} \mathrm{ha}^{-1}$ resulted in the longest panicle, the highest number of grains panicle ${ }^{-1}$ and 1000-grain weight due to increasing levels of nitrogen in combination with organic manures [30]. In another study, the highest number of effective tillers hill ${ }^{-1}$, panicle length and number of grains panicle ${ }^{-1}$ were observed from integrated (fertilizer + FYM) treatment 50\% recommended N-P-K @ 120-60-60 kg ha ${ }^{-1}$ and 50\% recommended $\mathrm{N}$ through FYM and $5 \mathrm{~kg}$ zinc ha ${ }^{-1}$ due to increase in photosynthesis activity of leaves, translocation of photosynthates from source to sink and nu- 
trients uptake under higher nutrients availability [31]. In addition, Thakuria and Thakuria, [32] documented that green manuring with dhaincha @ $40 \mathrm{~kg} \mathrm{ha}^{-1}$ and organic sources with enriched compost @ $10 \mathrm{t} \mathrm{ha}^{-1}$ produced the longest panicle, maximum number of filled grains panicle ${ }^{-1}$ and 1000-grain weight of scented rice variety joha.

\subsection{Role of Nutrient Management on Grain and Straw Yield}

Yield is one of the most important and complex traits in rice. Yield is determined by indirect traits like plant height, growth period, tillering ability, panicle length, seed length, seed setting rate, and grains per panicle as well as direct traits like panicle number per unit area and/or per plant, filled grains panicle ${ }^{-1}$ and 1000-grain-weight [33] [34] [35]. In a study, Paul et al. [21] documented that $100 \mathrm{~kg} \mathrm{~N} \mathrm{ha}^{-1}$ along with $90 \mathrm{~kg} \mathrm{~K} \mathrm{ha}^{-1}$ produced the highest grain (Figure 9) and straw yield of aromatic rice (cv. BRRI dhan50). Curtailed 25\% from the RDF of N-P-K-S-Zn@250-126-120-100-10 kg, respectively along with PM@ $2.5 \mathrm{t}$ $\mathrm{ha}^{-1}$ produced higher straw yield of aromatic rice [36] (Figure 10). As a source of nitrogen, application of USG $1.8 \mathrm{~g} 4$ hills $^{-1}$ increased grain and straw yield of aromatic rice [37]. Similar result was reported by Ferdush et al. [38] who revealed that the highest grain and straw yield of BRRI dhan34 were found in the treatment where $40 \mathrm{~kg} \mathrm{~N} \mathrm{ha}^{-1}$ was applied. While, the application of cowdung @ $5 \mathrm{t} \mathrm{ha} \mathrm{h}^{-1}+\mathrm{RDF}$ of N-P-K-S-Zn @ 150,60,50,30, $2.25 \mathrm{~kg} \mathrm{ha}^{-1}$, respectively showed a positive response on the yield components and finally led to the highest grain yield of BRRI dhan50 [39]. In a different study, Hossain et al. [40] stated that poultry litter @ $3 \mathrm{t} \mathrm{ha}^{-1}$ gave the highest grain and straw yield of aromatic rice compared to other treatments. On the other hand, the highest grain yield was recorded from USG $1.8 \mathrm{~g}_{4}$ hills $^{-1}\left(100 \mathrm{~kg} \mathrm{ha}^{-1}\right)$ and other inorganic fertilizer (i.e. 60, 40, 10 and $5 \mathrm{~kg} \mathrm{ha}^{-1}$ of $\mathrm{P}_{2} \mathrm{O}_{5}, \mathrm{~K}_{2} \mathrm{O}, \mathrm{S}$ and $\mathrm{ZnSO}_{4}$, respectively)

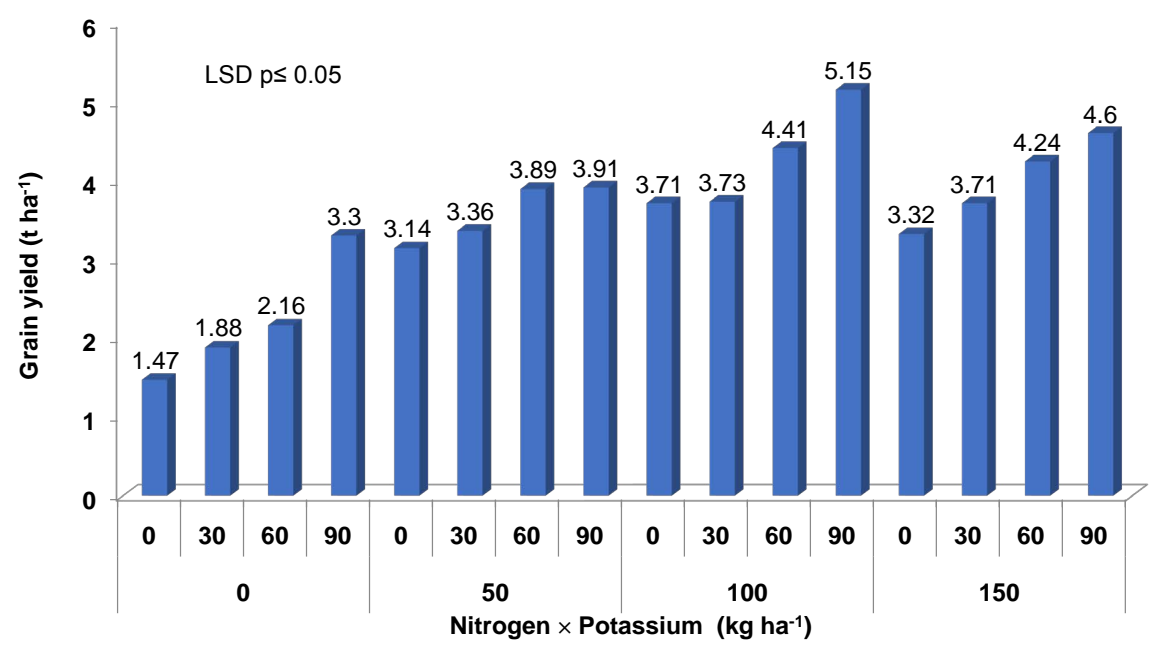

Figure 9. Interaction effects of level of nitrogen and level of potassium on grain yield of fine aromatic Boro rice (cv. BRRI dhan50). N = 0, 50, 100 and $150 \mathrm{~kg} \mathrm{ha}^{-1}, \mathrm{~K}=0,30,60$ and $90 \mathrm{~kg} \mathrm{ha}^{-1}$. Source: Paul et al. [21]. 


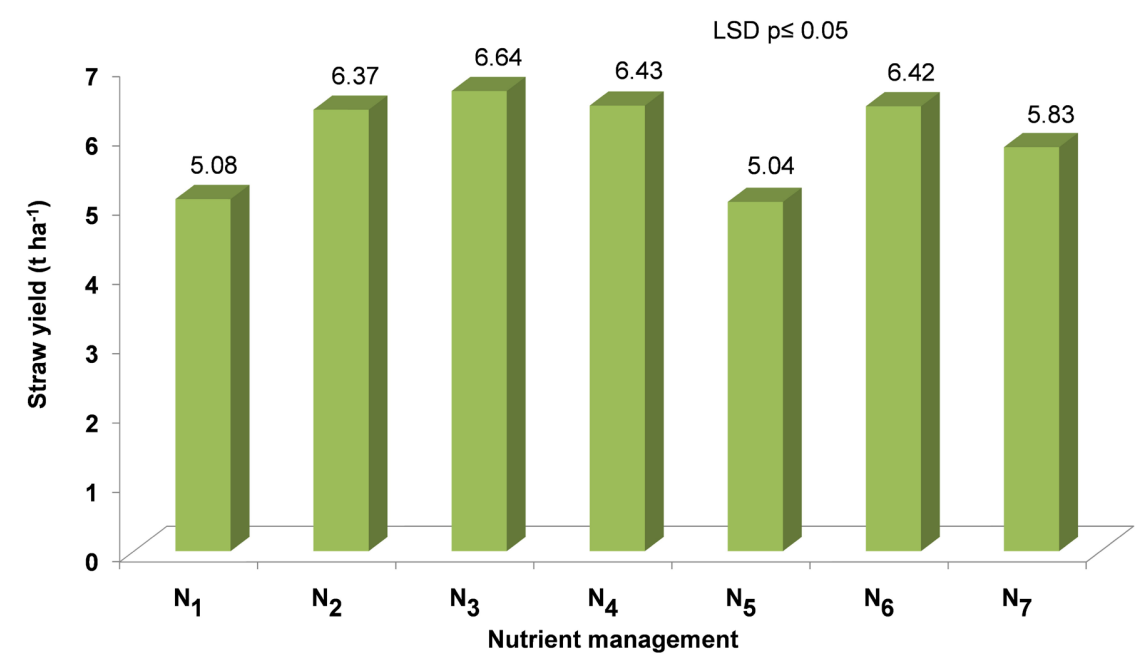

Figure 10. Effects of nutrient management on straw yield of aromatic Boro rice. $\mathrm{N}_{1}=\mathrm{PM}$ @ $5 \mathrm{t} \mathrm{ha}^{-1}, \mathrm{~N}_{2}=\mathrm{N}-\mathrm{P}-\mathrm{K}-\mathrm{S}-\mathrm{Zn} @ 250,126,120,100,10 \mathrm{~kg} \mathrm{ha}^{-1}$ (RDF), $\mathrm{N}_{3}=25 \%$ less than $\mathrm{RDF}+\mathrm{PM} @ 2.5 \mathrm{t} \mathrm{ha}^{-1}, \mathrm{~N}_{4}=50 \%$ less than RDF + PM@ $5 \mathrm{t} \mathrm{ha}^{-1}, \mathrm{~N}_{5}=$ vermicompost @ $10 \mathrm{t} \mathrm{ha}^{-1}, \mathrm{~N}_{6}=25 \%$ less than RDF + vermicompost @ $5 \mathrm{t} \mathrm{ha}^{-1}, \mathrm{~N}_{7}=50 \%$ less than RDF + vermicompost @ $10 \mathrm{tha}^{-1}$. Source: Adhikari et al. [36].

full dose for T. aman + PM @ $3.5 \mathrm{t} \mathrm{ha}^{-1}$ [41]. In addition, Islam et al. [42] documented that in case of silicon rates, $600 \mathrm{~kg} \mathrm{ha}^{-1}$ silicon produced the highest grain yield of aromatic rice. While, application of $\mathrm{N}\left(150 \mathrm{~kg} \mathrm{ha}^{-1}\right)$ at three equal splits, $1 / 3$ at 15 days after transplanting $+1 / 3$ at 30 days after transplanting $+1 / 3$ at 45 days after transplanting gave the highest grain yield as split of nitrogen met up of appropriate quantity of nitrogen for the crop demand [43]. Again, Basmati PNR gave higher grain yield when crops were grown in continuous standing water condition using the appropriate amount of nitrogen (105-140 $\left.\mathrm{kg} \mathrm{ha}^{-1}\right)$ [44]. On the other hand, Marzia et al. [45] revealed that the highest grain and straw yield of aromatic rice were obtained when the crop was fertilized with $75 \%$ of RDF of urea-TSP-MoP, gypsum- $\mathrm{ZnSO}_{4} @ 150-100-70-60-10 \mathrm{~kg}$, respectively $\mathrm{ha}^{-1}+$ cowdung @ $5 \mathrm{t} \mathrm{ha}^{-1}$ due to adequate availability and absorption of more nutrients. In addition, the treatment $50 \%$ from the RDF of $\mathrm{N}^{-} \mathrm{P}_{2} \mathrm{O}_{5}-\mathrm{K}_{2} \mathrm{O} @$ 50-25-25 kg ha ${ }^{-1}$, respectively + 50\% FYM @ $5 \mathrm{t} \mathrm{ha}^{-1}$ producing significantly higher grain yield due to well decomposition of FYM, which favoured better nutrient availability coupled with higher assimilation of nutrients [46]. While, from a field experiment the grain and straw yield of basmati increased significantly in treatment where FYM @ $19.76 \mathrm{t} \mathrm{ha}^{-1}$ and 50\% of recommended nitrogen (i.e. 40 $\mathrm{kg} \mathrm{N} \mathrm{ha}^{-1}$ ) was applied [47]. On the other hand, application of $75 \%$ organic + 25\% inorganic nutrient management FYM@8.2 t ha ${ }^{-1}+$ vermicompost @ $3.7 \mathrm{t}$ $\mathrm{ha}^{-1}+$ urea @ $65 \mathrm{~kg} \mathrm{ha}^{-1}$ recorded the highest grain yield of basmati rice due to quick release of nutrients in available form from decomposition of soil organic matter and applied manures [48]. Application of 100\% N-P-K @ 100-50-50 kg $\mathrm{ha}^{-1}$, respectively $+5 \mathrm{t} \mathrm{ha}^{-1} \mathrm{FYM}$ increased grain yield was reported by Kumar et al. [49]. In a study, application of green manuring @ $5 \mathrm{tha}^{-1}+\mathrm{FYM} @ 10 \mathrm{tha}^{-1}$ 
produced higher grain and straw yield of Birsamati than all other sources due to enhanced nutrient uptake by making linkage with a part of nutrient elements preventing the leaching and other losses [50]. On the other hand, Rehman et al. [51] reported that maximum grain and straw yield were recorded from foliage application of 0.32 M Boron. While, Saquib et al. [52] stated that the grain yield of Pusa Basmati 1121 was maximized with the application of organic sources neem cake @ $3 \mathrm{t} \mathrm{ha}^{-1}$ along with RDF of N-P-K ha ${ }^{-1} @ 100-40-30 \mathrm{~kg}$, respectively due to higher availability of both the native and applied nutrients and better source and sink relationship. Again, the treatment receiving $1.0 \mathrm{t} \mathrm{ha}^{-1}$ mustard cake and inorganic fertilizer @ $\mathrm{N}_{40} \mathrm{P}_{20} \mathrm{~K}_{20} \mathrm{~kg} \mathrm{ha}^{-1}$ improved soil productivity and increased fertilizer use efficiency, which registered the highest grain and straw yield of Gobindobhog rice [53]. Meanwhile, Sharma et al. [54] revealed that application of $\mathrm{N}_{90} \mathrm{P}_{45} \mathrm{~kg} \mathrm{ha}^{-1}$ increased the grain and straw yield of basmati cultivars over rest of the treatments. In addition, application of boron-coated urea at $0.5 \%\left(1.40 \mathrm{~kg} \mathrm{~B} \mathrm{ha}^{-1}\right)$, sulfur-coated urea at $5.0 \%\left(14.13 \mathrm{~kg} \mathrm{~S} \mathrm{ha}^{-1}\right)$ and zinc-coated urea (zinc sulfate heptahydrate-ZnSHH) @ 2.5\% (7.05 kg Zn ha $\left.{ }^{-1}\right)$ resulted in maximum grain and straw yield [55]. Another experiment revealed that the highest grain and straw yield were obtained from the highest level of $\mathrm{N}$ nutrition $\left(180 \mathrm{~kg} \mathrm{ha}^{-1}\right)$ over the other doses [56]. While, a study was conducted in north western plain zone of India, where, the maximum grain yield of fine rice Navya was recorded from the application of N-P-K @ 150-80-40 kg $\mathrm{ha}^{-1}$, respectively + two $\mathrm{Zn}$ spray $0.5 \%$ [1]. Again, application of RDF of $\mathrm{N}-\mathrm{P}_{2} \mathrm{O}_{5}-\mathrm{K}_{2} \mathrm{O} @ 60-40-20 \mathrm{~kg} \mathrm{ha}^{-1}+\mathrm{FYM} @ 5 \mathrm{tha}^{-1}+$ vermicompost @ $2.5 \mathrm{t} \mathrm{ha}^{-1}$ produced significantly the highest grain and straw yield due to slow release of major and micro nutrients which have catalytic role in photosynthate assimilation and translocation of metabolites [2]. Meanwhile, Bezbaruha et al. [57] stated that application of RDF of N- $\mathrm{P}_{2} \mathrm{O}_{5}-\mathrm{K}_{2} \mathrm{O} @ 140-60-60 \mathrm{~kg} \mathrm{ha}{ }^{-1}$ recorded the maximum grain yield of $\mathrm{CNRH} 3$ due to quick release and availability of nutrients in the crop field.

\subsection{Role of Nutrient Management on Grain Protein Content}

The highest grain protein content of BRRI dhan50 was found from USG $2.7 \mathrm{~g} 4$ hills ${ }^{-1}\left(80 \mathrm{~kg} \mathrm{~N} \mathrm{ha}^{-1}\right)+\mathrm{PM} @ 5 \mathrm{t} \mathrm{ha}^{-1}$, which indicated that combined application of manures with inorganic fertilizers enhanced grain protein content compared to sole application in aromatic Boro rice [58]. In a study, Islam et al. [59] reported that due to an adequate supply of nitrogen, the highest grain protein content was obtained from $50 \%$ of $\mathrm{RDF}+50 \%$ cowdung $\left(5 \mathrm{tha}^{-1}\right)$. On the other hand, 75\% of RDF of urea-TSP-MoP-gypsum- $\mathrm{ZnSO}_{4}$ @ 150-120-80-60-10 kg ha-1, respectively) + cowdung @ $10 \mathrm{tha}^{-1}$ gave the highest grain protein content [60]. Application of $25 \%$ less than RDF from urea-TSP-MoP-gypsum-ZnSO $\mathrm{Z}_{4} @ 250$ 120-120-100-10 kg ha ${ }^{-1}$, respectively + PM @ $2.5 \mathrm{t} \mathrm{ha}^{-1}$ gave the highest grain protein content of BRRI dhan 50 due to integration of PM with chemical fertilizer [61]. In addition, Roy et al. [62] reported that due to availability and uptake of 
adequate nitrogen from the soil, application of 75\% of RDF (urea-TSP-MoPgypsum- $\mathrm{ZnSO}_{4} @$ 250-120-120-100-10 kg ha ${ }^{-1}$, respectively)+PM @ $2.5 \mathrm{t} \mathrm{ha}^{-1}$ showed the highest grain protein content of BRRI dhan50 (Figure 11). While, a pot experiment was conducted in the farm shade house of Sher-e-Bangla Agricultural University, Dhaka, where application of $10 \mathrm{~kg} \mathrm{ZnSO}_{4} \mathrm{ha}^{-1}$ along with 4 $\mathrm{kg} \mathrm{ZnSO}_{4} \mathrm{ha}^{-1}$ (supplementation) produced the highest grain protein content [63]. On the other hand, according to Sarkar et al. [64] the highest grain protein content was found from $75 \%$ of RDF (i.e. urea-TSP-MoP-gypsum-zinc sulphate @ 150-97-70-60-12 $\mathrm{kg} \mathrm{ha}^{-1}$, respectively) + PM @ $2.5 \mathrm{t} \mathrm{ha}^{-1}$. In a study Sumon et al. [65] observed that green manure @ $17.5 \mathrm{t} \mathrm{ha}^{-1}$ gave the highest grain protein content than other treatments in the experiment. Meanwhile, Bora et al. [66] recorded that the highest grain protein content of Keteki joha was found higher with application of enriched compost @ $2.5 \mathrm{t} \mathrm{ha}^{-1}$ due to differential release of nutrients from organic sources. In addition, application of $150 \mathrm{~kg} \mathrm{~N} \mathrm{ha}^{-1}$ in three splits increased kernel protein content in comparison to the basal application of $\mathrm{N}$ [67]. Another field experiment revealed that with $\mathrm{N}$ application, the highest protein content of fine rice was recorded from $60 \mathrm{~kg} \mathrm{~N}$ $\mathrm{ha}^{-1}$ compared to other $\mathrm{N}$ doses [68]. Again, NPK application @ 100\% of RDF (80-40-20 kg ha-1) and combined application of FYM@10 $\mathrm{t} \mathrm{ha}^{-1}+$ blue green algae (BGA) @ $10 \mathrm{~kg} \mathrm{ha}^{-1}$ produced the highest grain protein content of aromatic rice variety HUR-917 as integration of bio-organic sources increased the availability of nitrogen and other nutrients to the plant [3]. While, Mahata et al. [69] stated that the integrated nutrient management dose of FYM @ $5 \mathrm{t} \mathrm{ha}^{-1}$ $+\mathrm{N}_{40} \mathrm{P}_{20} \mathrm{~K}_{20} \mathrm{~kg} \mathrm{ha}^{-1}$ adopted for Gobindabhog rice for higher grain protein content.

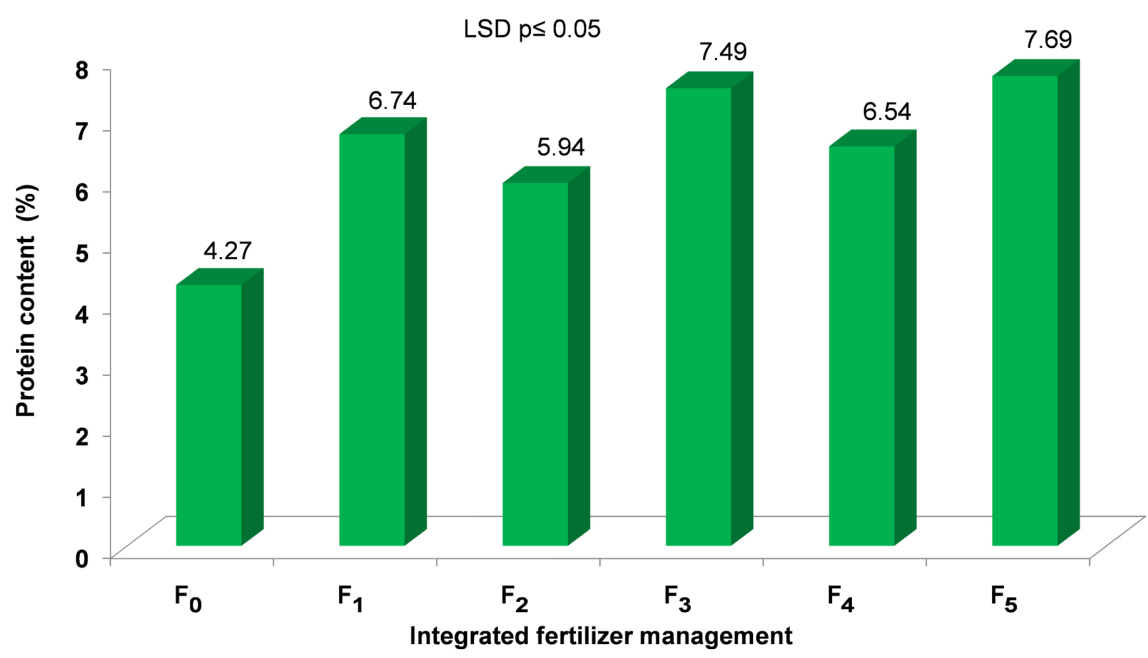

Figure 11. Effect of integrated fertilizer management on grain protein content of aromatic Boro rice (cv. BRRI dhan50). $\mathrm{F}_{0}=$ Control (no fertilizer and no manure), $\mathrm{F}_{1}=\mathrm{RDF}$ (Urea, TSP, MoP, gypsum, $\mathrm{ZnSO}_{4} @ 250,120,120,100,10 \mathrm{~kg} \mathrm{ha}^{-1}$, respectively), $\mathrm{F}_{2}=50 \%$ of RDF + cowdung @ $5 \mathrm{t} \mathrm{ha}^{-1}, \mathrm{~F}_{3}=75 \%$ of RDF + cowdung @ $5 \mathrm{t} \mathrm{ha}^{-1}, \mathrm{~F}_{4}=50 \%$ of RDF + PM@ $2.5 \mathrm{t} \mathrm{ha}^{-1}, \mathrm{~F}_{5}=75 \%$ of RDF + PM @ $2.5 \mathrm{t} \mathrm{ha}^{-1}$. Source: Roy et al. [62]. 


\section{Conclusion}

Fragrant rice productivity is a serious concern to the world for cooking qualities and high market price. Proper nutrient management maintained soil physical condition and increased crop production which is the basic need for the cultivation of sustainable agriculture. Application of an optimum dose of chemical fertilizers increases fertility status of soil, maintains adequate soil available nutrients, saves environmental contamination and ensures farmer's profit. Whereas, an injudicious application of chemical fertilizers decreases soil productivity, increases farmer's cost and impedes the environment. The application of organic manures is also important for maximizing rice productivity. In the rice field, addition of organic manures can compensate for the negative effects on soil health due to excessive application of chemical fertilizers. Combined application of manure and chemical fertilizer exerted significant influence on growth, yield contributing characters, yield and grain quality of rice by making the field favorable for production. The rate of manure and fertilizer application differed with soil physical, chemical and biological properties. Practicing any nutrient management model with target yield is helpful for the better utilization of the available resources of the poor farmer. In addition, efficient nutrient management for sustainable rice production ensures better soil fertility with higher crop productivity and promises least environmental pollution. Therefore, nutrient management is the single most important factor in context of growth, yield and grain quality of fragrant rice that should be given the highest priority for profitable rice production.

\section{Conflicts of Interest}

The authors declare no conflicts of interest regarding the publication of this paper.

\section{References}

[1] Singh, V., Singh, V., Singh, S. and Khanna, R. (2020) Effect of Zinc and Silicon on Growth and Yield of Aromatic Rice (Oryza sativa) in North-Western Plains of India. Journal of Rice Research and Developments, 3, 82-86. https://doi.org/10.36959/973/424

[2] Teli, N.A., Bhat, M.A., Hussain, A., Ahangar, M.A., Ganaie, M.A. and Jehangir, I.A. (2018) Response of High Valued Scented Rice to Integrated Nutrient Management under Temperate Agro Climatic Conditions. International Journal of Current Microbiology and Applied Sciences, 7, 3496-3502. https://doi.org/10.20546/ijcmas.2018.703.402

[3] Kumar, N., Kumar, S., Sravan, U.S. and Singh, S.P. (2017) Growth and Yield Performance of Aromatic Rice (Oryza sativa L.) as Influenced by Bio-Organics and Fertility Levels. Journal of Pharmacognosy and Phytochemistry, 6, 2131-2136.

[4] Sinha, T., Paul, S.K. and Sarkar, M.A.R. (2018) Effect of Age of Seedlings at Staggered Transplanting and Weed Management on the Growth and Yield of Aromatic Boro Rice (cv. BRRI dhan50). Journal of Bangladesh Agricultural University, 16, 
5-11.

[5] Singh, R.P., Jaiswal, H.K. and Madhavilatha, L. (2006) HUBR 2-1 (Malviya Basmati Dhan 1), a New, High-Yielding Basmati Rice Variety for Cultivation in Eastern India. International Rice Research Notes, 31, 33-34.

[6] Prodhan, S.B. (1992) Status of Fertilizer Use in Developing Countries of Asia and Pacific Region. Proceedings of the Regional FADINAP Seminar on Fertilization and the Environment, Chiang Mai, 7-11 September 1992, 37-47.

[7] Satyanarayana V., Murthy V.R.K., Vara Prasad P.V. and Boote K.J. (2002) Influence of Integrated Use of Farmyard Manure and Inorganic Fertilizers on Yield and Yield Components of Irrigated Lowland Rice. Journal of Plant Nutrition, 25, 2081-2090. https://doi.org/10.1081/PLN-120014062

[8] Nayak, B., Rath, B.S., Shahid, M., Jena, S.N., Bagchi, T.B. and Roy, P.S. (2020) Organic Nutrient Management in Aromatic Rice-Rice Sequence: A Critical Review. International Journal of Chemical Studies, 8, 1435-1444. https://doi.org/10.22271/chemi.2020.v8.i5t.10503

[9] Javier E.F., Marquez J.M., Grospe F.S., Mamucod H.F. and Tabien R.E. (2004) Three-Year Effect of Organic Fertilizer Use on Paddy Rice. Philippine Journal of Crop Sciences, 27, 11-15.

[10] Gill J.S. and Walia S.S. (2014) Influence of FYM, Brown Manuring and Nitrogen Levels on Direct Seeded and Transplanted Rice (Oryza sativa L.): A Review. Research Journal of Agriculture and Environmental Management, 3, 417-426.

[11] Ye, T., Li, Y., Zhang, J., Hou, W., Zhou, W., Lu, J., Xing, Y. and Li, X. (2019) Nitrogen, Phosphorus, and Potassium Fertilization Affects the Flowering Time of Rice (Oryza sativa L.). Global Ecology and Conservation, 20, e00753. https://doi.org/10.1016/j.gecco.2019.e00753

[12] Di Mola, I., Ottaiano, L., Cozzolino, E., Senatore, M., Giordano, M., El-Nakhel, C., Sacco, A., Rouphael, Y., Colla, G. and Mori, M. (2019) Plant-Based Biostimulants Influence the Agronomical, Physiological, and Qualitative Responses of Baby Rocket Leaves under Diverse Nitrogen Conditions. Plants, 8, Article No. 522. https://doi.org/10.3390/plants8110522

[13] Mori, A., Fukuda, T., Vejchasarn, P., Nestler, J., Pariasca-Tanaka, J., Wissuwa, M. (2016) The Role of Root Size versus Root Efficiency in Phosphorus Acquisition in Rice. Journal of Experimental Botany, 67, 1179-1189. https://doi.org/10.1093/jxb/erv557

[14] Cakmak, I. (2005) The Role of Potassium in Alleviating Detrimental Effects of Abiotic Stresses in Plants. Journal of Plant Nutrition and Soil Science, 168, 521-530. https://doi.org/10.1002/jpln.200420485

[15] Kundu, A. Roy, A.K.S. and Patra, P.S. (2016) Responses of Integrated Nitrogen Management on the Performance of Aromatic Rice Varieties under Terai Zone of West Bengal. International Journal of Science, Environment and Technology, 5, 2406-2414.

[16] Nila, N.Y., Paul, S.K. and Sarkar, M.A.R. (2018) Growth Performance of Aromatic Boro Rice (Oryza sativa L. cv. BRRI dhan50) as Influenced by Date of Transplanting and Nutrient Management. Archives of Agriculture and Environmental Science, 3, 116-122. https://doi.org/10.26832/24566632.2018.030203

[17] Sarkar, S.K., Sarkar, M.A.R., Islam, N. and Paul, S.K. (2016) Morpho-Physiological Attributes of Three HYV Aromatic Fine Rice Varieties as Affected by Integrated Nutrient Management. Journal of Agroforestry and Environment, 10, 57-61. 
[18] Roy, A., Sarkar, M.A.R. and Paul, S.K. (2018) Effect of Age of Seedlings at Staggered Transplanting and Nutrient Management on Yield Performance of Aromatic Fine Rice (cv. BRRI dhan38). SAARC Journal of Agriculture, 16, 49-59.

[19] Roy, A., Sarkar, M.A.R., Rahman, A. and Paul, S.K. (2020) Effect of Age of Seedlings at Staggered Planting and Nutrient Management on the Growth Performance of Aromatic Fine Rice (Oryza sativa L. cv. BRRI dhan38). Archives of Agriculture and Environmental Science, 5, 130-136. https://doi.org/10.26832/24566632.2020.050207

[20] Roy, P., Md. Sarkar, M.A.R., Paul, N.C., Saha, K.K. and Paul, S.K. (2020) Response of Integrated Fertilizer and Weed Management on Weed Occurrence and Growth Traits of Aromatic Boro Rice. Archives of Agriculture and Environmental Science, 5, 337-346. https://doi.org/10.26832/24566632.2020.0503015

[21] Paul, N.C., Paul, S.K., Salam, M.A. and Paul, S.C. (2021) Dry Matter Partitioning, Yield and Grain Protein Content of Fine Aromatic Boro Rice (cv. BRRI dhan50) in Response to Nitrogen and Potassium Fertilization. Bangladesh Journal of Botany, 50, 103-111.

[22] Sharma, R., Gangwar, R.K., Yadav, V. and Kumar, R. (2014) Response of Basmati Rice (Oryza sativa) Cultivars to Graded Nitrogen Levels under Transplanted Condition. International Journal of Research in Applied, Natural and Social Sciences, 2, 33-38.

[23] Sharma, A., Singh, S.V., Patel, A. and Yadav, R.A. (2017) Growth and Yield of Scented Rice (Oryza sativa L.) as Influenced by Integrated Nutrient Management Practices. Research on Crops, 18, 409-414. https://doi.org/10.5958/2348-7542.2017.00071.7

[24] Fageria, N.K. (2007) Yield Physiology of Rice. Journal of Plant Nutrition, 30, 843-879. https://doi.org/10.1080/15226510701374831

[25] Hossain, M.E., Ahmed, S., Islam, M.T., Riaj, M.M.R., Haque, K.A. and Hassan, S.M.Z. (2018) Optimization of Nitrogen Rate for Three Aromatic Rice Varieties in Patuakhali Region. International Journal of Natural and Social Sciences, 5, 65-70.

[26] Jahan, M.S., Sultana, S. and Ali, M.Y. (2014) Effect of Different Nitrogen Levels on the Yield Performance of Aromatic Rice Varieties. Bulletin of the Institute of Tropical Agriculture, Kyushu University, 37, 47-56.

[27] Laila, N., Sarkar, M.A.R., Paul, S.K. and Rahman, A. (2020) Yield Performance of Aromatic Fine Rice as Influenced by Integrated Use of Vermicompost and Inorganic Fertilizers. Journal of Bangladesh Agricultural University, 18, 260-265.

[28] Mamun, A.A., Sarkar, M.A.R. and Uddin, F.M.J. (2010) Effect of Variety, Number of Seedling Hill-1 and Fertilizer Application on the Growth and Yield of Fine Rice under Late Transplanted Condition. Journal of Agroforestry and Environment, 4, 177-180.

[29] Paul, S.K., Nila, N.Y. and Sarkar, M.A.R. (2020) Grain Yield and Quality of Aromatic Boro Rice (cv. BRRI dhan50) Subject to Date of Transplanting and Nutrient Management. Thai Journal of Agricultural Science, 53, 85-96.

[30] Rathiya, P.S. Singh, V.K. and Kumar, R. (2017) Growth and Yield Performance of Aromatic Rice (Oryza sativa L.) Varieties as Affected by Various Nutrient Management Practices. Journal of Pharmacognosy and Phytochemistry, SP1, 866-868.

[31] Sharma, A.K., Singh, T., Patel, A. and Yadav, R.A. (2018) Influence of Integrated Nutrient Management Practices on Scented Rice (Oryza sativa L.) Pertaining to Eastern Uttar Pradesh. Journal of Pharmacognosy and Phytochemistry, 7, 1448-1453.

[32] Thakuria, K. and Thakuria, C. (2018) Influence of Green Manuring and Organic 
Sources of Nutrient Application on Scented Rice (Oryza sativa)-Linseed (Linum usitatissimum) Cropping System. Indian Journal of Agricultural Research, 52, 704-707.

[33] Moldenhauer, K. and Nathan, S. (2004) 1-Rice Growth and Development. In: Slaton, N., Ed., Rice Production Handbook, University of Arkansas, Arkansas, 01-38.

[34] Sakamoto, T. and Matsuoka, M. (2008) Identifying and Exploiting Grain Yield Genes in Rice. Current Opinion in Plant Biology, 11, 209-214. https://doi.org/10.1016/j.pbi.2008.01.009

[35] Huang, R., Jiang, L., Zheng, J., Wang, T., Wang, H., Huang, Y., et al. (2013) Genetic Bases of Rice Grain Shape: So Many Genes, So Little Known. Trends in Plant Science, 18, 218-226. https://doi.org/10.1016/j.tplants.2012.11.001

[36] Adhikari, A., Sarkar, M.A.R., Paul, S.K. and Saha, K.K. (2018) Impact of Nutrient Management on the Yield Performance of Some Aromatic Fine Rice (Oryza sativa L.) Varieties in Boro Season. Archives of Agriculture and Environmental Science, 3, 245-251. https://doi.org/10.26832/24566632.2018.030306

[37] Chowdhury, S.A., Paul, S.K. and Sarkar, M.A.R. (2016) Yield Performance of Fine Aromatic Rice in Response to Variety and Level of Nitrogen. Journal of Environmental Science and Natural Resources, 9, 41-45.

[38] Ferdush, J., Sarkar, M.A.R., Paul, S.K., Rahman, M.S., Talukderb, F.U. and Imran, S. (2020) Interaction Influence of Row Arrangement and Nitrogen Level on the growth and Yield of Transplant Aman Rice (BRRI dhan34). Sustainability in Food and Agriculture (SFNA), 1, 55-63. https://doi.org/10.26480/sfna.01.2020.55.63

[39] Hossain, M.F., Hasan, M.A. and Amin, M.H.A. (2010) Performance of Modern Aromatic Rice (cv. BRRI dhan50) under Different Fertilizer Management Practices in Boro Season. Journal of Agroforestry and Environment, 4, 147-149.

[40] Hossain, M.F., Hasan, M.A. Majumder, U.K. and Fancy, R. (2010) Effect of Poultry Litter, Cowdung and Chemical Fertilizers on the Performance of Basmati and Banglamati Aromatic Rice in Boro Season. Journal of Agroforestry and Environment, 4, 147-149.

[41] Islam, M.S., Sarkar, M.A.R., Uddin, S. and Parvin, S. (2012) Yield of Fine Rice Varieties as Influenced by Integrated Management of Poultry Manure Urea Super Granules and Prilled Urea. Journal of Environmental Science and Natural Resources, 5, 129-132.

[42] Islam, M.S., Islam, M.M., Rahman, M.H., Islam, M.F., Khanam, S., Ali, M. and Hye, M.A. (2017) Lodging Resistance, Growth and Yield of Selected Aromatic Rice Varieties in Relation to Application of Silicon. American Journal of Research Communication, 5, 25-32.

[43] Islam, M.S., Hakim, M.A., Hafeez, A.S.M.G., Bari, A.K.M.A. and Chowdhury, M.K. (2019) Splitting of Nitrogen Fertilizer Enhanced Growth, Yield Contributing Parameters and Yield of Aromatic Rice Varieties. ISPEC Journal of Agricultural Sciences, 3, 80-97.

[44] Mannan M.A., Bhuiya M.S.U., Akhand M.I.M. and Zaman M.M. (2012) Growth and Yield of Basmati and Traditional Aromatic Rice as Influenced by Water Stress and Nitrogen Level. Journal of Science Foundation, 10, 52-62.

[45] Marzia, R., Sarkar, M.A.R. and Paul, S.K. (2016) Effect of Row Arrangement and Integrated Nutrient Management on the Yield of Aromatic Fine Rice (cv. BRRI dhan34). International Journal of Plant \& Soil Science, 13, 1-8.

[46] Bhowmick, M.K., Dhara, M.C., Bag, M.K., Adhikari, B. and Kundu, C. (2011) Inte- 
grated Nutrient Management for Aromatic Rice in West Bengal. Oryza, 48, 276-277.

[47] Gill, P.K. and Aulakh, C.S. (2018) Effect of Integrated Nitrogen Management on NPK Uptake in Basmati Rice (Oryza sativa L.). Journal of Applied and Natural Science, 10, 258-261.

[48] Jat, N.K., Yadav, R.S., Kumar, S., Shamim, M., Ravisankar, N., Babu, S. and Panwar, A.S. (2019) Influence of Different Nutrient Management Practices on Productivity, Profitability and Nutrient Dynamics in Basmati Rice (Oryza sativa)-Wheat (Triticum aestivum) Cropping Systems in Western Indo-Gangetic Plains of India. Indian Journal of Agricultural Sciences, 89, 793-799.

[49] Kumar, R., Zaidi, S.F.A., Singh, G., Kumar, B. and Nishad, K.K. (2016) Effect of Integrated Nutrient Management on Yield and Phosphorus Availability of Aromatic Rice (Oryza sativa L.) in Inceptisol of Eastern U. P. Advance Research Journal of Crop Improvement, 7, 145-147. https://doi.org/10.15740/HAS/ARJCI/7.1/145-147

[50] Kumari, N., Pal, S.K. and Barla, S. (2013) Effect of Organic Nutrient Management on Productivity and Economics of Scented Rice. Oryza, 50, 249-252.

[51] Rehman, A., Farooq, M., Cheema, Z.A., Nawaz, A. and Wahid, A. (2014) Foliage Applied Boron Improves the Panicle Fertility, Yield and Biofortification of Fine Grain Aromatic Rice. Journal of Soil Science and Plant Nutrition, 14, 723-733.

[52] Saquib, M., Singh, R., Kumar, H., Yadav, M.P. and Khan, N. (2017) Superimposition of Organic Sources of Manures to Enhance Yield and Quality Parameters of Scented Rice (Oryza sativa L.) in Indo-Gangetic Plain Zone. Plant Archives, 17, 1765-1768.

[53] Sasmal, S. and Pal, S.K. (2018) Effect of Integrated Nutrition in Aromatic Rice on Carbon and Nutrient Status in an Inceptisol. Communications in Soil Science and Plant Analysis, 49, 30-37. https://doi.org/10.1080/00103624.2017.1421216

[54] Sharma, D., Sagwal, P.K., Singh, I. and Sangwan, A. (2012) Influence of Different Nitrogen and Phosphorus Levels on Profitability, Plant Nutrient Content, Yield and Quality in Basmati Cultivars. International Journal of IT, Engineering and Applied Sciences Research (IJIEASR), 1, 4 p.

[55] Shivay, Y.S., Pooniya, V., Pal, M., Ghasal, P.C., Bana, R. and Jat, S.L. (2019) Coated Urea Materials for Improving Yields, Profitability and Nutrient Use Efficiencies of Aromatic Rice. Global Challenges, 3, Article ID: 1900013. https://doi.org/10.1002/gch2.201900013

[56] Singh, T., Shivay, Y.S. and Singh, S. (2004) Effect of Date of Transplanting and Nitrogen on Productivity and Nitrogen Use Indices in Hybrid and Non-Hybrid Aromatic Rice. Acta Agronomica Hungarica, 52, 245-252.

https://doi.org/10.1556/AAgr.52.2004.3.5

[57] Bezbaruha, R., Sharma, R.C. and Banik, P. (2011) Effect of Nutrient Management and Planting Geometry on Productivity of Hybrid Rice (Oryza sativa L.) Cultivars. American Journal of Plant Sciences, 2, 297-302. https://doi.org/10.4236/ajps.2011.23033

[58] Biswas, T., Paul, S.K., Sarkar, M.A.R. and Sarkar, S.K. (2016) Integrated Use of Poultry Manure with Prilled Urea and Urea Super Granules for Improving Yield and Protein Content of Aromatic Rice (cv. BRRI dhan50). Progressive Agriculture, 27, 86-93.

[59] Islam, S.S., Roshid, M.A.M.O., Sikdar, M.S.I., Hasan, A.K. and Hossain, M.S. (2021) Growth and Yield Performance of Aromatic Fine Rice as Influenced by Varieties 
and Fertilizer Managements. Journal of Applied Agricultural Science and Technology, 5, 1-12. https://doi.org/10.32530/jaast.v5i1.6

[60] Pal, S., Paul, S.K., Sarkar, M.A.R. and. Gupta, D.R. (2016) Response on Yield and Protein Content of Fine Aromatic Rice Varieties to Integrated Use of Cowdung and Inorganic Fertilizers. Journal of Crop and Weed, 12, 1-6.

[61] Paul, S.K., Ray, M.C., Sarkar, M.A.R. and Sarkar, S.K. (2019) Effect of Water, Nutrient and Weed Management on the Yield and Quality of Aromatic Boro Rice (CV. BRRI dhan50). Bangladesh Agronomy Journal, 22, 57-69.

[62] Roy, P., Sarkar, M.A.R. and Paul, S.K. (2017) Yield and Grain Protein Content of Aromatic Boro rice (cv. BRRI dhan50) as Influenced by Integrated Fertilizer and Weed Management. International Journal of Applied Sciences and Biotechnology, 5, 51-58.

[63] Roy, T.S., Roy, A., Ali, M., Chakraborty, R., Mostofa, M., Mahato, A.K., Sumon, M.M.H. and Sultana, N. (2019) Organoleptic and Grain Quality Traits of Aromatic Rice Varieties as Influenced by Supplementation of $\mathrm{Zn}$ and 2-Acetyl-1-Pyrroline. Plant Science Today, 6, 518-527.

[64] Sarkar, S.K., Sarkar, M.A.R., Islam, N. and Paul, S.K. (2014) Yield and Quality of Aromatic Fine Rice as Affected by Variety and Nutrient Management. Journal of the Bangladesh Agricultural University, 12, 279-284.

[65] Sumon, M.J.I., Roy, T.S., Haque, M.N., Ahmed, S. and Mondal, K. (2018) Growth, Yield and Proximate Composition of Aromatic Rice as Influenced by Inorganic and Organic Fertilizer Management. Notulae Scientia Biologicae, 10, 211-219. https://doi.org/10.15835/nsb10210260

[66] Bora, D., Goswami, J., Saud, R.K. and Begum1, M. (2014) Effect of Organic Inputs on Production and Quality of Scented Rice (Oryza sativa) Variety Keteki joha in Assam and Its Economic Aspect. Agricultural Science Digest, 34, 115-118. https://doi.org/10.5958/0976-0547.2014.00027.5

[67] Ishfaq, M., Akbar, N., Zulfiqar, U., Hussain, S., Murtza, K., Batool, Z., Ashraf, U., Alyemeni, M.N. and Ahmad, P. (2020) Influence of Nitrogen Management Regimes on Milling Recovery and Grain Quality of Aromatic Rice in Different Rice Production Systems. Agronomy, 10, Article No. 1841. https://doi.org/10.3390/agronomy10111841

[68] Javeed, A., Gupta, M. and Gupta, V. (2017) Effect of Graded Levels of N, P \& K on Growth, Yield and Quality of Fine Rice Cultivar (Oryza sativa L.) under Subtropical Conditions. SSARSC International Journal of Management, 3, 8 p.

[69] Mahata, D., Ghosh, M., Patra, B.C., Pal, S.K. and Banerjee, S. (2019) Standardization of Integrated Nutrient Management for Aromatic Gobindabhog Rice in Gangetic Alluvial Region of West Bengal. Journal of Crop and Weed, 15, 87-92.

https://doi.org/10.22271/09746315.2019.v15.i3.1242 